\title{
Population Dynamics and Within-Tussock-Succession in a Carex sempervirens Subalpine Grassland in the Swiss Alps
}

\author{
Fei-Hai Yu ${ }^{*}, 1,2$, Bertil O. Krüsi ${ }^{1,4}$, Martin Schütz ${ }^{1}$, Jakob Schneller ${ }^{2}$ and Otto Wildi ${ }^{1}$ \\ ${ }^{I}$ Swiss Federal Institute for Forest, Snow and Landscape Research, Zürcherstrasse 111, CH-8903 Birmensdorf, \\ Switzerland \\ ${ }^{2}$ State Key Laboratory of Vegetation and Environmental Change, Institute of Botany, Chinese Academy of Sciences, \\ Beijing 100093, China \\ ${ }^{3}$ Institute of Systematic Botany, University of Zürich, Zollikerstrasse 107, CH-8008 Zürich, Switzerland \\ ${ }^{4}$ University of Applied Sciences Zürich-Wädenswil (ZHAW), Grüental Postfach 335, 8820 Wädenswil, Switzerland
}

\begin{abstract}
Tussock-forming graminoids play an important role in high-altitude grasslands. In tussocks many other plant species can grow, forming small communities. However, little is known about such small-scale vegetation, especially during succession. In an abandoned subalpine pasture in the Swiss National Park, we studied population dynamics and within-tussock vegetation of Carex sempervirens in four successional grassland stages (i.e. early, young, mature and senescent) distinguished at community level. At population level, we observed a succession process encompassing both directional and cyclic elements. In agreement with a decrease in grazing pressure and tussock vitality, similarity of the vegetation within tussocks decreased from the early to the senescent stage. Within-tussock vegetation of the early stage was more similar to that of the young stage than to that of the mature and the senescent stage. Fuzzy ordination revealed a similar pathway of succession in C. sempervirens tussocks as observed at community level. We conclude that successional transition from grassland to forest may encompass more than one $C$. sempervirens cycle and with each cycle floristic composition both inside and outside $C$. sempervirens tussocks will become more similar to the subsequent forest stage.
\end{abstract}

Keywords: Caespitose graminoids, evergreen sedge, secondary succession, Swiss National Park, within-tussock vegetation.

\section{INTRODUCTION}

Economically, traditional agriculture and forestry currently applied in the Alps are becoming increasingly less viable, so that considerable areas of subalpine and alpine grasslands will be abandoned and undergo secondary succession $[1,2]$. Vegetation succession is generally considered as either a directional process [3] or a cyclic one [4-9]. However, succession may also be a spiral process, i.e. a largescale, long-term directional process that encompasses smallscale, short-term cycles of vegetation changes [8].

Vegetation dynamics and succession may be viewed as population-based processes, and characterized as the replacement of dominant plant species over time [10-12]. In many ecosystems, especially in wetlands, tundra and highaltitude grasslands, tussock-forming species play a central role in structuring community and in vegetation succession [13-19]. Therefore, to understand succession processes in these ecosystems and develop spatially and temporally sound succession models, knowledge on the underlying population dynamics of the tussock plants are crucial [20].

In tussocks of some caespitose species many other plant species can grow, forming small plant communities.

*Address correspondence to this author at the State key Laboratory of Vegetation and Environmental Change, Institute of Botany, Chinese Academy of Sciences, Beijing 100093, China; Tel: +86 10 62836635, Fax: +86 10 82594676; E-mail: feihaiyu@ibcas.ac.cn
Examples of such tussock-forming species include Molinia caerulea in wet heathlands of Great Britain [21], Eriophorum vaginatum in the tundra of Alaska [22], Carex stricta in freshwater wetlands of North American [18], and Carex sempervirens in alpine and subalpine grasslands of Central Europe [23,24].

In tussocks micro-environmental conditions (e.g. light, temperature, water and nutrients) and biological processes (e.g. competition, grazing, litter decomposition and nutrient cycling) are very likely to be different from the surrounding areas [19,22,25-30]. Consequently, floristic composition in tussocks is very likely to be different from that outside the tussocks [31,32]. Individual tussocks thus may be treated as small 'island' communities [18]. Up to date, however, only little attention has been paid to these within-tussock communities $[18,31,32]$.

The present study deals with the role of the tussockforming sedge Carex sempervirens in the succession of an abandoned subalpine grassland in the Swiss National Park. We focused on tussock density, vitality and size distribution at population level, as well as on floristic composition at within-tussock level. Specifically, we addressed the following questions: (1) How does the population structure of $C$. sempervirens change during grassland succession? (2) What type of succession (cyclic, directional or spiral) is supported by the population data? (3) Does the floristic composition of the small-scale plant communities within tussocks of $C$. sempervirens change with the successional stage of the 
grassland where the tussocks grow? (4) If so, are these changes at the scale of tussocks independent of the surrounding vegetation or do they mirror the changes observed at community level?

\section{MATERIALS AND METHODS}

\section{The Species}

Carex sempervirens Vill. (evergreen sedge) is a perennial tussock-forming, 20-60 $\mathrm{cm}$ tall sedge [33]. In the mountain ranges of Central and Southern Europe, C. sempervirens is quite frequent and often dominates nutrient-poor grasslands both below and above the timberline [33]. Tussocks of $C$. sempervirens have a well-defined, more or less cylindrical base that consists of densely packed tiller stems, fine roots and litter. In $C$. sempervirens tussocks we found many different vascular plant species. Most frequent were Galium pusillum L. (89\%), Briza media L. (76\%), Campanula scheuchzeri Vill. (63\%), Ranunculus montanus Willd. (58\%), Trifolium repens L. (58\%), Phyteuma orbiculare L. (52\%), F. rubra (42\%), Achillea millefolium L. (40\%), Polygonum viviparum L. (37\%) and Crepis alpestris (Jacq.) Tausch $(36 \%)[23,24]$.

\section{Study Site}

The study was carried out in the Swiss National Park (SNP), located in the Engadine valley of the Central Alps. The SNP ranges in altitude from 1400 to $3174 \mathrm{~m}$ a.s.l. and covers $170 \mathrm{~km}^{2}$, of which $29 \%$ are occupied by forest, $21 \%$ by alpine and subalpine grasslands, and $50 \%$ by unproductive terrain [34]. The Swiss Meteorological Institute recorded in the SNP (Buffalora, 1917-2003) an annual temperature of $0.27 \pm 0.67^{\circ} \mathrm{C}$ (mean $\pm 1 \mathrm{SD}$ ) and an annual precipitation of $926 \pm 162 \mathrm{~mm}$. The soil substrate in the SNP is mainly derived from dolomitic sediments [34].

The SNP is one of the few areas in the Alps where all agricultural, silvicultural and hunting activities have been completely banned for most of the $20^{\text {th }}$ century (since1914). In $1917 \mathrm{~J}$. Braun-Blanquet started to monitor vegetation change by establishing the first of more than 160 permanent plots [34-36]. Starting in 1918, every year, the wild ungulates present in the SNP were counted [37]. The $20^{\text {th }}$ century was marked by a sharp increase in the density of red deer (Cervus elaphus L.), from nil in 1920 to about 20 per vegetation-covered $\mathrm{km}^{2}$ in 1970 (range 1970-99: 17.9 to 27.9 per $\mathrm{km}^{2}$ ). In 1999, in addition to 1824 red deer, 1624 chamois (Rupicapra rupicapra L.), 395 ibex (Capra ibex L.) and a few roe deer (Capreolus capreolus L.) were counted [37].

The study area, Alp Stabelchod, is an abandoned subalpine pasture, 10.7 ha in size, facing southwest with a slope of about $6^{\circ}$ and ranging in altitude from 1920 to $1980 \mathrm{~m}$ a.s.1.. In the middle ages, Alp Stabelchod was created by cutting and possibly burning the pristine forest. During the following centuries, Alp Stabelchod was used as pasture for sheep and cattle [34]. At the time when the SNP was founded in 1914, the vegetation on Alp Stabelchod was not uniform but showed the typical pattern of subalpine pastures with distinct nutrient, grazing and succession gradients from the hut to the forest edge $[2,34,38,39]$. Compared to the extremely nutrient-rich but ungrazed tall-herb communities near the stable and the adjacent heavily grazed pasture, the nutrient-poor and undergrazed areas near the forest edge corresponded already at the time of abandonment to a fairly advanced successional stage. Between 1914 and 1940 succession proceeded very slowly but largely undisturbed and with little impact on the pattern present at the time when commercial grazing was stopped [35,36]. After 1940 red deer started to use the most nutrient-rich parts of the pasture, transforming the tall-herb communities and the more nutrient-rich parts of the pasture into a shortgrass sward dominated by red fescue (Festuca rubra) [36,40].

On Alp Stabelchod, vegetation change after the cessation of commercial grazing and following the re-immigration of red deer was monitored on more than 10 permanent plots. The permanent plot data clearly demonstrate that the plant communities present today on Alp Stabelchod represents a series of successional stages $[35,36,40,41]$.

\section{Sampling Design}

Achermann (2000) subdivided Alp Stabelchod into 268 plots, each $20 \mathrm{~m} \times 20 \mathrm{~m}$ in size [40]. In each plot, percentage cover of each vascular plant species was estimated within an $1 \mathrm{~m} \times 1 \mathrm{~m}$ subplot [40]. In addition, phosphorous content in the top soil and grazing pressure by red deer were also measured $[40,42]$.

Based on the floristic releves of Achermann (2000) [40] and the successionally relevant species groups distinguished in the succession model of Wildi and Schütz (2000) [43], each plot was assigned to one of four successional stages characterized by the dominance of (i) F. rubra, (ii) F. rubra and $C$. sempervirens, (iii) C. sempervirens, and (iv) C. sempervirens and Sesleria coerulea (L.) Ard., respectively. With regard to number and vitality of tussocks of the evergreen sedge $C$. sempervirens, we labeled the four stages as follows: (i) early (C. sempervirens is very rare), (ii) young (C. sempervirens population is building up), (iii) mature (C. sempervirens is dominant) and (iv) senescent ( $C$. sempervirens population is getting weaker). Spatially, the four stages form more or less concentrical circles around the place where formerly the stable was located. From the early to the senescent stage, soil phosphorous content and grazing pressure by red deer decreased, whereas species richness in the $1-\mathrm{m}^{2}$ plots and cumulative species richness in $201-\mathrm{m}^{2}$ subplots increased (Table 1).

In each of the four successional stages, we randomly selected five plots. In each of the 20 selected plots, we then randomly selected $30 \mathrm{C}$. sempervirens tussocks. In every selected $C$. sempervirens tussock, we recorded name and percentage cover of each vascular plant species rooting inside the tussock base. Diameter of tussock base was measured as an indicator of tussock size. In addition, we measured the following tussock vitality parameters: height of tussock base $(B H)$, maximum diameter of tussock canopy $(M D)$, maximum and average height of tussock canopy $(\mathrm{MH}$ and $A H$ ), number of inflorescences of $C$. sempervirens $(I N)$, tussock canopy cover $(C C)$ and cover of litter on tussock base $(L C)$. Population density of $C$. sempervirens tussocks in each plot was estimated using nearest distance method based on 30 distance measures [44].

\section{Data Analysis}

We used a nested MANOVA (plots nested within successional stages) followed by pairwise contrasts on vitality re- 
Table 1. Description of the Four Successional Stages Based on Data from Leuzinger (1999), Achermann (2000), Wildi and Schütz (2000) and Schütz et al. (2000b) [40-43]. Mean $\pm 1 \mathrm{SE}$ is Given. Within One Line, Means Sharing the Same Letter are Not Different at $\boldsymbol{P} \leq \mathbf{0 . 0 5}$ (ANOVA Followed by Student-Newman-Keuls Tests)

\begin{tabular}{|c|c|c|c|c|}
\hline Parameter & Early & Young & Mature & Senescent \\
\hline Number of plots & 37 & 50 & 106 & 75 \\
\hline Phosphorous content (mg.kg $\left.{ }^{-1}\right)$ & $240.7 \pm 7.5 \mathrm{a}$ & $205.8 \pm 6.8 \mathrm{~b}$ & $172.7 \pm 4.1 \mathrm{c}$ & $161.6 \pm 5.1 \mathrm{c}$ \\
\hline \multicolumn{5}{|c|}{ Species Richness } \\
\hline No. of species in $201-\mathrm{m}^{2}$ subplots & $72.0 \pm 0.6 \mathrm{c}$ & $80.6 \pm 2.4 \mathrm{ab}$ & $79.0 \pm 1.9 \mathrm{~b}$ & $84.4 \pm 1.2 \mathrm{a}$ \\
\hline No. of species per $1-\mathrm{m}^{2}$ subplot & $27.9 \pm 1.0 \mathrm{~b}$ & $31.8 \pm 0.6 \mathrm{a}$ & $30.6 \pm 0.5 \mathrm{a}$ & $31.1 \pm 0.7 \mathrm{a}$ \\
\hline \multicolumn{5}{|c|}{ Grazing Pressure (Mainly By Red Deer) } \\
\hline No. of grazing deer per plot ${ }^{*}$ & $20.2 \pm 2.6 \mathrm{a}$ & $20.7 \pm 2.7 \mathrm{a}$ & $6.3 \pm 1.1 \mathrm{~b}$ & $5.8 \pm 1.2 b$ \\
\hline No. of faecal-pellets per plot & $26.9 \pm 1.8 \mathrm{a}$ & $23.3 \pm 1.7 \mathrm{a}$ & $15.4 \pm 0.9 \mathrm{~b}$ & $17.4 \pm 1.1 \mathrm{~b}$ \\
\hline Cover of short grass $(\%)$ & $78.1 \pm 4.3 \mathrm{a}$ & $57.9 \pm 4.9 \mathrm{~b}$ & $19.5 \pm 2.5 \mathrm{c}$ & $20.8 \pm 3.0 \mathrm{c}$ \\
\hline \multicolumn{5}{|c|}{ Cover of Successionally Important Species (\%) } \\
\hline Festuca rubra & $13.4 \pm 1.4 \mathrm{a}$ & $6.5 \pm 0.9 b$ & $2.9 \pm 0.4 \mathrm{c}$ & $5.1 \pm 0.5 b$ \\
\hline Carex sempervirens & $1.0 \pm 0.4 \mathrm{c}$ & $7.0 \pm 1.1 \mathrm{~b}$ & $28.2 \pm 1.7 \mathrm{a}$ & $5.7 \pm 0.8 \mathrm{~b}$ \\
\hline Sesleria coerulea & $0.0 \pm 0.0 \mathrm{c}$ & $0.7 \pm 0.3 \mathrm{c}$ & $7.6 \pm 0.8 b$ & $20.5 \pm 1.6 \mathrm{a}$ \\
\hline
\end{tabular}

"Observed during 54 nights between May and September of 1998 (Leuzinger, 1999) [42].

lated measures $(B H, M D, M H, A H, I N, C C$ and $L C)$ to determine if the vitality of $C$. sempervirens differed among the four successional stages [45]. Since we expected that $C$. sempervirens would become weak in the senescent stage, we also examined the difference between the senescent stage and the pooled early, young and mature stages [46]. A nested ANOVA followed by pairwise contrasts was also applied to each tussock trait to examine if it differed among the four stages. Differences in tussock density and size distribution among the four stages were examined by Kruskal-Wallis tests and Kolmogorov-Smirnov tests, respectively [46].

We calculated the similarity (i) between the vegetation inside $C$. sempervirens tussocks of the same successional stage, and (ii) between the vegetation inside $C$. sempervirens tussocks of different successional stages, based on the following index [47],

$S_{x, y}=\frac{\sum x_{i} y_{i}}{\sum x_{i}^{2}+\sum y_{i}^{2}-\sum x_{i} y_{i}}(i=1,2, \ldots, n)$

where $S_{x, y}$ is the vegetation similarity between tussocks $x$ and $y, x_{i}$ and $y_{i}$ are the scores of species $i$ in tussocks $x$ and $y$, and $n$ is the number of species. Using fuzzy ordination [48] with Mulva 5 software [49], we also examined if the vegetation inside $C$. sempervirens tussocks showed a similar succession pathway as observed at community level. The $1^{\text {st }}$ and $2^{\text {nd }}$ fuzzy ordination axis were defined by the vegetation outside $C$. sempervirens tussocks using the averaged relevé of Achermann (2000) [40] from the early and the senescent stage, respectively. Fuzzy ordination here determines the degree of belonging of the vegetation inside tussocks to the vegetation outside tussocks of the early stage $\left(1^{\text {st }}\right.$ ordination axis) and of the senescent stage ( $2^{\text {nd }}$ axis), and is based on the same similarity index as described above. Irrespective of the transformation of the data (untransformed or square-root transformed cover data or presence-absence data), the resulting pattern was basically the same, so that we only presented the result from the untransformed relevés. For similarity caculation and Fuzzy ordination, we used only tussocks with a basal diameter $\geq 15 \mathrm{~cm}$.

\section{RESULTS}

\section{Population Density}

Population density of $C$. sempervirens was highest in the mature stage ( 82215 tussocks $\mathrm{ha}^{-1}$ ) and lowest in the early stage (5395 tussocks ha ${ }^{-1}$ ), and there was no marked difference between the senescent (12420 tussocks ha $\left.{ }^{-1}\right)$ and the young stage (12585 tussocks ha ${ }^{-1}$, Fig. (1)).

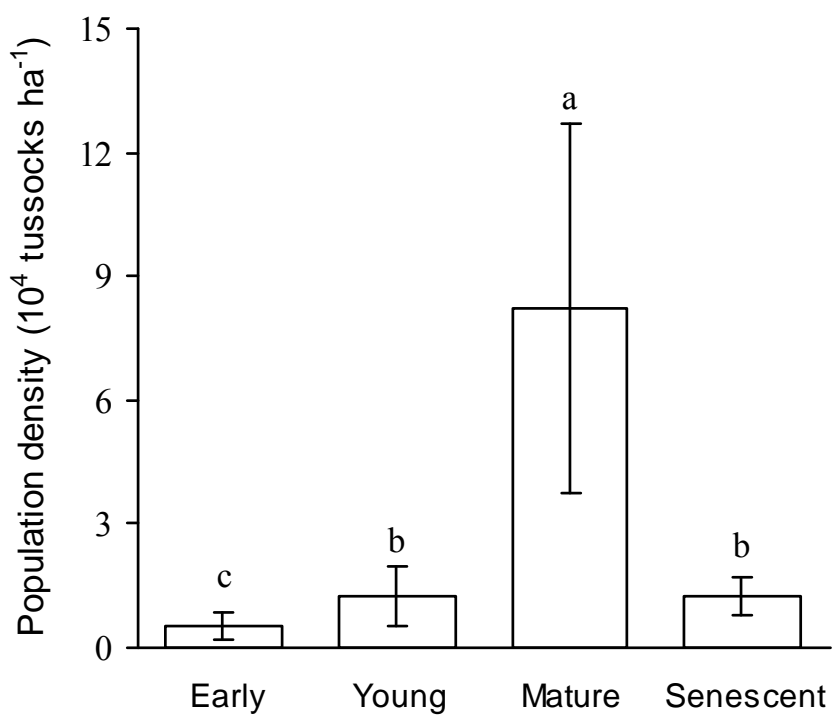

Fig. (1). Population density of Carex sempervirens in the four successional stages. Mean $\pm 1 \mathrm{SE}$ is given. Bars sharing the same letter are not different at $P=0.05$ (Kruskal-Wallis tests). 


\section{Size Distribution}

Size distributions of $C$. sempervirens tussocks in the early and the mature stage were significantly different and they also differed significantly from those in the young and the senescent stage (Fig. 2). However, no marked difference was found between the senescent and the young stage. Regarding large tussocks with a basal diameter $\geq 15 \mathrm{~cm}$, the highest proportion $(36.0 \%)$ was found in the mature stage, followed by $19.3 \%$ in the young stage, and then $16.7 \%$ in both the early and the senescent stages (Fig. 2). Concerning small tussocks with a basal diameter $<5 \mathrm{~cm}$, however, the highest proportions were found both in the young (33.3\%) and the senescent stage $(32.7 \%)$, followed by the mature $(19.3 \%)$ and the early stage (16.0\%; Fig. (2)).

\section{Tussock Vitality}

Nested MANOVA revealed significant differences in the vitality of $C$. sempervirens tussocks among the four successional stages (Wilks' $\lambda=0.0423, \mathrm{~F}=2.80, P=0.0052$ ). On the whole, vitality of $C$. sempervirens was the lowest in the senescent stage (Table 2B), as the tussocks were smaller, with regard to height and diameter, and weaker, as indicated by the low cover of $C$. sempervirens, the high cover of litter and the small number of inflorescences (Table 2A). However, vitality of $C$. sempervirens did not show marked differences among the early, the young and the mature stage (Table 2A,B).

\section{Within-Tussock Vegetation}

Similarity between vegetation in C. sempervirens tussocks with a basal diameter $\geq 15 \mathrm{~cm}$ decreased from the two earlier stages (early 0.55 and young 0.51 ) to the two later stages (mature 0.32 and senescent 0.37; Fig. (3)). Withintussock vegetation of the early stage was more similar to that of the young stage $(0.48)$ than to that of the mature $(0.27)$ and the senescent stage (0.14). Similarly, within-tussock vegetation of the young stage was more similar to that of the early than to that of the mature $(0.29)$ and the senescent stage (0.20; Fig. (3)).

Scores of the $1^{\text {st }}$ and $2^{\text {nd }}$ Fuzzy ordination axes differed significantly among the four successional stages (KruskalWallis test: $1^{\text {st }}$ axis scores, $\chi^{2}=39.85, P<0.001 ; 2^{\text {nd }}$ axis scores, $\chi^{2}=52.60, P<0.001$; Fig. (4)). Within-tussock vegetation had a clear gradient along the $2^{\text {nd }}$ ordination axis. Along the $1^{\text {st }}$ ordination axis, significant differences were also found between the two earlier and the two later stages (Mann-Whitney tests: $P<0.05$ for all comparisons), but not between the mature and the senescent stage (Mann-Whitney test: $\mathrm{U}=705.0, P=0.940)$, or between the young and the early stage ( $\mathrm{U}=337.5, P=0.197$; Fig. (4)).

\section{DISCUSSION}

\section{Population Level}

In a directional succession process, one expects the dominant species to peak in abundance and vitality in the mature stage. One also expects that from the early to the senescent stage the fraction of small (presumably young) tussocks decreases and that of large (presumably old) ones increases. In the present study with $C$. sempervirens, the patterns of cover, density and vitality of tussocks matched the expectations. Regarding size distribution, however, the senescent stage was identical to the young stage but markedly different from the mature stage. Also, contrary to expectations, we found high fractions of small tussocks (basal diameter $<5 \mathrm{~cm}$ ) in both the young and the senescent stage. Size distributions of C. sempervirens tussocks, therefore, suggest that the senescent stage may be followed by another mature stage, i.e. a cyclic pathway of succession.

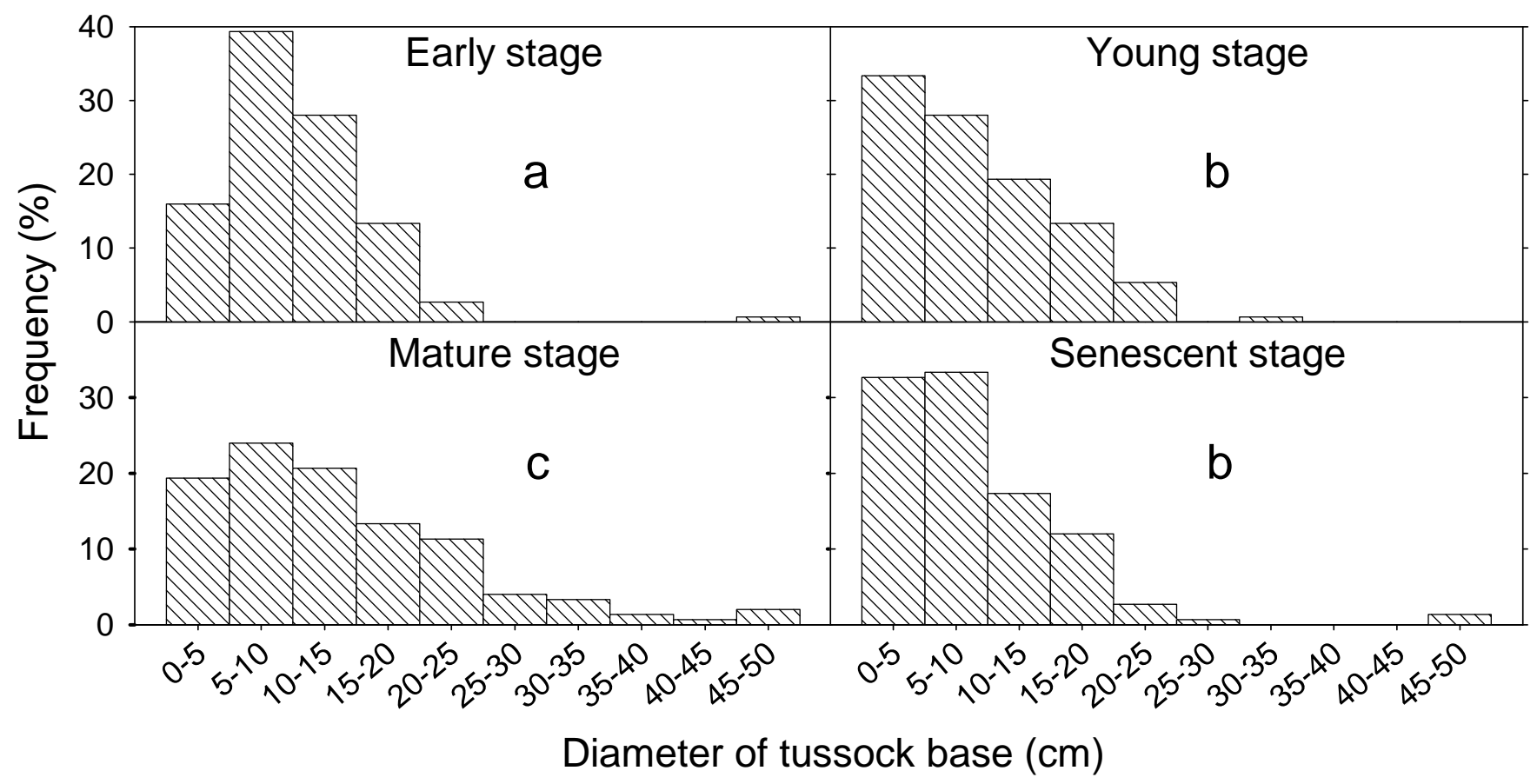

Fig. (2). Size distribution of Carex sempervirens tussocks in the four successional stages. Panels with the same letters in the middle indicate no difference in size distribution at $P=0.05$ (Kolmogorov-Smirnov tests). 
Table 2. Comparisons of Vitality Measures of Carex sempervirens in the Four Successional Stages. (A) Mean \pm 1 SE is Indicated. For Each Vitality Measure, Means Sharing the Same Letter are Not Different at $P=0.05$ (Nested ANOVA Followed by Pairwise Contrasts). (B) Pairwise Contrasts and the Contrast of Senescent Stage vs the Pooled Early, Young and Mature Stages (Nested MANOVA)

\begin{tabular}{|c|c|c|c|c|}
\hline (A) Vitality Measure & Early & Young & Mature & Senescent \\
\hline Height of tussock base $(\mathrm{cm})$ & $3.8 \pm 0.21 \mathrm{a}$ & $3.2 \pm 0.31 \mathrm{~b}$ & $3.9 \pm 0.28 \mathrm{a}$ & $2.5 \pm 0.19 \mathrm{c}$ \\
\hline Maximum diameter of tussock canopy $(\mathrm{cm})$ & $33.7 \pm 1.6 \mathrm{a}$ & $29.7 \pm 2.9 b$ & $33.4 \pm 2.6 \mathrm{a}$ & $27.5 \pm 2.6 b$ \\
\hline No. of inflorescences per tussock & $6.6 \pm 1.1 \mathrm{a}$ & $7.1 \pm 1.9 \mathrm{a}$ & $8.6 \pm 1.6 \mathrm{a}$ & $3.8 \pm 0.8 \mathrm{~b}$ \\
\hline Maximum height of tussock canopy $(\mathrm{cm})$ & $29.1 \pm 1.5 \mathrm{a}$ & $24.0 \pm 1.4 \mathrm{c}$ & $26.5 \pm 1.2 \mathrm{~b}$ & $24.2 \pm 1.9 \mathrm{c}$ \\
\hline Average height of tussock canopy $(\mathrm{cm})$ & $16.8 \pm 1.1 \mathrm{a}$ & $15.6 \pm 1.1 \mathrm{ab}$ & $16.1 \pm 0.8 \mathrm{a}$ & $14.7 \pm 1.0 \mathrm{~b}$ \\
\hline Tussock canopy cover on tussock base (\%) & $69.8 \pm 2.3 \mathrm{a}$ & $62.7 \pm 1.2 \mathrm{~b}$ & $63.3 \pm 3.2 b$ & $60.8 \pm 4.4 \mathrm{~b}$ \\
\hline Litter cover on tussock base (\%) & $15.8 \pm 2.8 b$ & $17.7 \pm 3.0 \mathrm{~b}$ & $29.4 \pm 5.3 \mathrm{a}$ & $29.0 \pm 4.5 \mathrm{a}$ \\
\hline
\end{tabular}

\begin{tabular}{|c|c|c|c|c|c|}
\hline (B) Contrast & & Early & Young & Mature & Early + Young + Mature \\
\hline \multirow{4}{*}{ Young } & Wilks' $\lambda$ & 0.3221 & & & \\
\hline & $\mathrm{F}$ & 3.01 & & & \\
\hline & $\mathrm{DF}$ & 7,10 & & & \\
\hline & $P$ & 0.0563 & & & \\
\hline \multirow{4}{*}{ Mature } & Wilks' $\lambda$ & 0.4593 & 0.4163 & & \\
\hline & $\mathrm{F}$ & 1.68 & 2.00 & & \\
\hline & DF & 7,10 & 7,10 & & \\
\hline & $P$ & 0.2198 & 0.1540 & & \\
\hline \multirow{4}{*}{ Senescent } & Wilks' $\lambda$ & 0.2342 & 0.2160 & 0.3699 & 0.2424 \\
\hline & $\mathrm{F}$ & 4.67 & 4.04 & 2.43 & 4.47 \\
\hline & DF & 7,10 & 7,10 & 7,10 & 7,10 \\
\hline & $P$ & 0.0145 & 0.0232 & 0.0980 & 0.0168 \\
\hline
\end{tabular}

One argument is that the high fraction of small tussocks of $C$. sempervirens in the senescent stage could result from dieback and fragmentation of large, ageing tussocks, as observed in several bunchgrasses [26,50]. However, this was unlikely the case in the present study because we treated small ones that were close together and had a more or less continuous base as one large, ageing tussock. Also, using Randomly Amplified Polymorphic DNA (RAPD) markers, we found 300 randomly sampled $C$. sempervirens tussocks on the same site to be genetically distinct from one another ( $\mathrm{Yu}$ et al. unpubl. data). Differences in grazing pressure might greatly affect the size distributions of $C$. sempervirens tussocks due to the size-related selective grazing, but this could not explain the higher fractions of small tussocks in the senescent stages as compared to the mature stage.

Not in agreement with a purely cyclic succession, however, were the data on tussock vitality, as indicated e.g. by the number of inflorescences produced, and the finding that the percentage of small tussocks (basal diameter $<5 \mathrm{~cm}$ ) was highest in the young and the senescent but not in the early stage. We believe that this is due to the activities of red deer which graze most heavily in the early stage and which presumably avoid $C$. sempervirens tussocks only when they have reached a certain size.

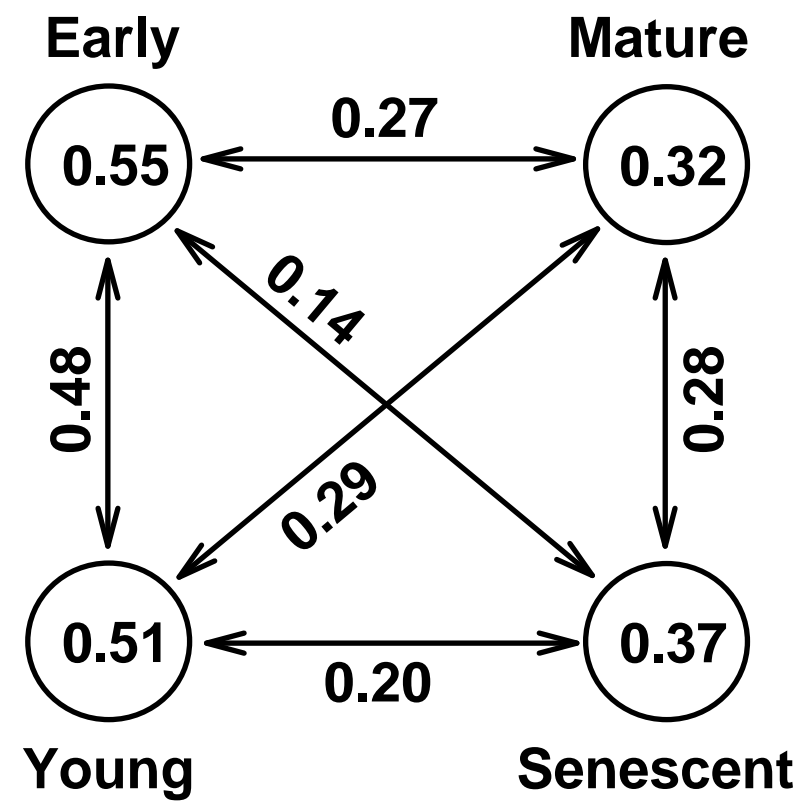

Fig. (3). Similarity between vegetation in Carex sempervirens tussocks of the same stage (figures inside the circles), and of different stages (figures adjacent to the arrowed lines). 


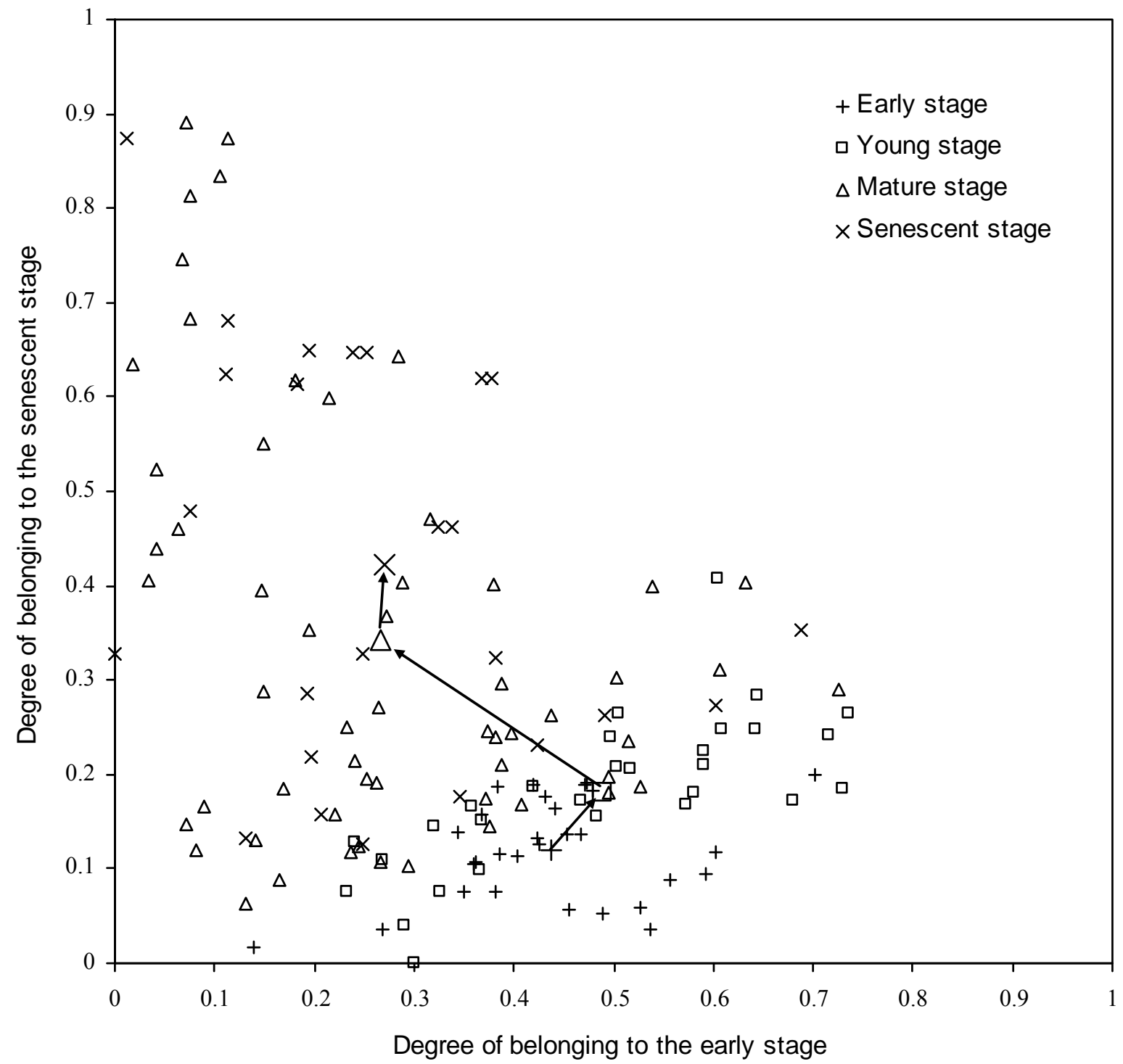

Fig. (4). Fuzzy ordination determining the degree of belonging of within-tussock vegetation to vegetation outside tussocks of the early stage $\left(1^{\text {st }}\right.$ ordination axis) and of the senescent stage $\left(2^{\text {nd }}\right.$ ordination axis). The four larger symbols represent the mean values of similarity of the four corresponding successional stages. The lines with arrows indicate the succession pathway.

On Alp Stabelchod, we hypothesize from the population data that more than one cycle (generation) of C. sempervirens may be needed before species of the subsequent succession stage such as pine trees (Pinus montana and $P$. cembra) can successfully establish. A successful establishment of the species of the subsequent successional stage is only possible if the presently dominating $C$. sempervirens becomes sufficiently weak. This may be caused by one or a combination of the following factors: (i) a catastrophic event such as a drought or a disease [8,51], (ii) a slow but continuous $C$. sempervirens-related change in site conditions $[8,9]$ or (iii) a slow genetic impoverishment of the population of the dominant species, which makes it less fit to deal with unfavourable events $[52,53]$.

\section{Tussock Level}

Carex sempervirens forms clearly defined tussocks that accumulate at their base substantial amounts of densely packed litter. Conditions inside tussocks are, therefore, most likely to be different from those in the adjacent vegetation. In particular, this should hold true for the early and the young stage where the vegetation outside tussocks is heavily grazed while the tussocks are especially vigorous and avoided by red deer. In North California, tussocks of Carex nudata were found to be able to protect the plant species growing in them from herbivores [31]. In Alaska tundra, soils thawed faster, reached maximum summer temperature sooner, and were warmer and thermally more stable inside than outside tussocks of Eriophorum vaginatum [19]. Litter decomposition rate and nutrient cycling seemed also to be much faster inside than outside the tussocks [19]. In different ecosystems, tussocks plants were found to be able to accumulate nitrogen and carbon immediately beneath them and formed 'island of fertility' [26-30].

In the present study we thus assumed the vegetation to reflect the different site conditions inside and outside tussocks of $C$. sempervirens, and expected the vegetation inside tussocks to be different among the successional stages. 
Analysis of relevés inside $C$. sempervirens tussocks revealed, indeed, marked differences between the successional stages. In agreement with the decrease in tussock vitality and grazing pressure, the similarity of within-tussock vegetation decreased from the early to the senescent stage. Also withintussock vegetation of the early stage was more similar to that of the young stage than to that of the mature and the senescent stages. We expected this because of (i) the abovementioned differences in tussock vitality and (ii) the marked differences in the adjacent vegetation and site conditions. Fuzzy ordination revealed a clear relationship between the vegetation inside and outside tussocks of $C$. sempervirens: within-tussock vegetation in a given successional stage was most similar to the surrounding vegetation of the same stage. Inside tussocks of $C$. sempervirens, we found, therefore, a similar successional pathway observed at community level, i.e. the directional succession described by the model of Wildi and Schütz (2000) [43] and Schütz et al. (2000b) [41].

\section{CONCLUSIONS}

We conclude that on Alp Stabelchod the successional transition from grassland to forest may encompass more than one $C$. sempervirens cycle (i.e. generation). We hypothesize that, with each cycle, floristic composition both inside and outside $C$. sempervirens tussocks will become more similar to the subsequent forest stage. With each cycle, density and vitality, possibly also genetic variability, of $C$. sempervirens will decrease, rendering $C$. sempervirens populations weaker and less able to compete with species from the subsequent forest stage. We also hypothesize that $C$. sempervirens brings about successional change in a twofold way: First, by occupying space, i.e. by reducing the living space of species that are unable to grow or at least to survive inside $C$. sempervirens tussocks; Second, by altering site conditions, for instance, by (i) eliminating grazing and the associated disturbances and nutrient flows [54], (ii) by accumulating litter, toxic substances, pathogens or nutrients, or (iii) by depleting specific nutrients [9]. We expect that $C$. sempervirens will eventually render site conditions unsuitable for itself.

\section{ACKNOWLEDGEMENTS}

We thank the Scientific Council of the Swiss National Park for the permission to carry out the field work and three anonymous reviewers for comments on an early version of the manuscript. This research was financially supported by the Swiss National Fund No. 3100-064158.00/1.

\section{REFERENCES}

[1] Risch AC, Schütz M, Krüsi B, Kienast F, Bugmann H. Long-term empirical data as a basis for the analysis of successional pathways in subalpine conifer forests. Austrian J Forest Sci 2003; 120: 59-64. Schütz M, Risch AC, Leuzinger E, Krüsi B, Achermann G. Impact of herbivory by red deer (Cervus elaphus L.) on patterns and processes in subalpine grasslands in the Swiss National Park. Forest Ecol Manage 2003; 181: 177-188.

[3] Clements FE. Plant succession: an analysis of the development of vegetation. Washington: Carnegie; 1916.

[4] Mueller-Dombois D. Perspectives for an etiology of stand-level dieback. Annu Rev Ecol Syst 1986; 17: 221-243.

[5] Barclay-Estrup P, Gimingham $\mathrm{CH}$. The description and interpretation of cyclical processes in heath community. I. Vegetational change in relation to the Calluna cycle. J Ecol 1969; 57: 737-758.

[6] Larocque I, Bergeron Y, Campbell ID, Bradshaw RHW. Vegetation changes through time on islands of Lake Duparquet, Abitibi, Canada. Can J Forest Res 2000; 30: 179-190.
Watt AS. Pattern and process in the plant community. J Ecol 1947; 35: $1-22$.

[8] Remmert H. The mosaic-cycle concept of ecosystems - an overview. In: Remmert H, Eds. The mosaic-cycle concept of ecosystems. Berlin, Springer-Verlag 1991; 1-21.

[9] Bokdam J. Effects of browsing and grazing on cyclic succession in nutrient-limited ecosystems. J Veg Sci 2001; 12: 875-886.

[10] Falinska K. Plant demography in vegetation succession. Dordrecht: Kluwer Academic Publishers; 1991.

[11] van der Maarel E. Vegetation dynamics: patterns in time and space. Vegetatio 1988; 77: 7-19.

[12] Glenn-Lewin DC, van der Maarel E. Patterns and processes of vegetation dynamics. In: Glenn-Lewin DC, Peet R, Veblen TT, Eds. Plant succession: theory and prediction. London, Chapman \& Hall, 1992; 11-59.

[13] Körner C. Alpine plant diversity: a global survey and functional interpretations. In: Chapin FSI, Körner C, Eds. Arctic and alpine biodiversity. Berlin, Springer-Verlag, 1995; 45-62.

[14] Körner C. Alpine plant life: functional plant ecology of high mountain ecosystems. New York: Springer; 1999.

[15] Erschbamer B, Buratti U, Winkler J. Long-term population dynamics of two Carex curvula species in the Central Alps on native and alien soils. Oecologia 1998; 115: 114-119.

[16] Rose AB, Platt KH. Age-stages, population structure, and seedling regeneration of Chionochloa pallens in Canterbury alpine grasslands, New Zealand. J Veg Sci 1990; 1: 89-96.

[17] Fetcher N, Shaver GR. Growth and tillering patterns with tussocks of Eriophorum vaginatum. Holarctic Ecol 1982; 5: 180-186.

[18] Lord LA, Lee TD. Interactions of local and regional processes: species richness in tussock sedge communities. Ecology 2001; 82: 313-318.

[19] Chapin FS III, van Cleve K, Chapin MC. Soil temperature and nutrient cycling in the tussock growth form of Eriophorum vaginatum. J Ecol 1979; 67: 169-189.

[20] Silvertown J, Charlesworth D. Introduction to plant population biology. Oxford: Blackwell; 2001.

[21] Rutter AJ. The composition of wet-heath vegetation in relation to the water table. J Ecol 1955; 43: 507-543.

[22] Fetcher N. Effects of removal of neighboring species on growth, nutrients, and microclimate of Eriophorum vaginatum. Arctic Alpine Res 1985; 17: 7-17.

[23] Yu F-H, Schneller J, Krüsi B, Schütz M, Tang M, Wildi O. Genetic variability within Carex sempervirens tussocks of contrasting vitality. Int J Plant Sci 2006; 167: 513-518.

[24] Yu F-H, Krüsi B, Schütz M, Schneller J, Wildi O. Is vegetation inside Carex sempervirens tussocks highly specific or basically an image of the surrounding vegetation? J Veg Sci 2006; 17: 567-571.

[25] Nishikawa Y. Role of rhizomes in tussock formation by Carex thunbergii var. appendiculata. Ecol Res 1990; 5: 5261-269.

[26] Briske DD, Derner JD. Clonal biology of caespitose grasses. In: Cheplick G, Ed. Population biology of grasses. Cambridge, Cambridge Unversity Press, 1998; 106-135.

[27] Derner JD, Briske DD, Boutton TW. Does grazing mediate soil carbon and nitrogen accumulation beneath $\mathrm{C}_{4}$, perennial grasses along an environmental gradient? Plant Soil 1997; 191: 147-156.

[28] Hook PB, Burke IC, Lauenroth WK. Heterogeneity of soil and plant $\mathrm{N}$ and $\mathrm{C}$ associated with individual plants and openings in North American shortgrass steppe. Plant Soil 1991; 138: 247-256.

[29] Vinton MA, Burke IC. Interactions between individual plant species and soil nutrient status in shortgrass steppe. Ecology 1995; 76 : 1116-1133.

[30] Jackson RB, Caldwell MM. Geostatistical pattern of soil heterogeneity around individual perennial plants. J Ecol 1993; 81: 683-692.

[31] Levine JM. Complex interactions in a streamside plant community. Ecology 2000; 81: 3431-3444.

[32] Levine JM. Indirect facilitation: evidence and predictions from a riparian community. Ecology 1999; 80: 1762-1769.

[33] Hess H, Landolt E, Hirzel R. Flora der Schweiz und Angrenzender Gebiete. Basel: Birkhauser; 1967.

[34] Schütz M, Krüsi B, Edwards PJ. Succession research in the Swiss National Park. Zernez: Nat Park-Forsch Schweiz 89; 2000.

[35] Braun-Blanquet J. Vegetationsentwicklung im Schweizerischen Nationalpark. Ergebnisse der Untersuchung von Dauerflächen. Jahresber. Naturf. Ges. Graubündens N.F.; 1931.

[36] Stüssi B. Naturbedingte Entwicklung subalpiner Weiderasen auf Alp La Schera im Schweizer Nationalpark während der Reservats- 
periode 1939-1965. Ergebn. wissenschaftl. Untersuch. Schweiz. Nationalpark 13; 1970.

[37] Haller H. Der Rothirsch im Schweizerischen Nationalpark und dessen Umgebung. Eine Alpine Population von Cervus elaphus Zeitlich und Räumlich Dokumentiert. Zernez: Nat Park-Forsch Schweiz 91; 2002.

[38] Spatz G. Succession patterns on mountain pastures. Vegetatio 1980; 43: 39-41.

[39] Ellenberg H. Vegetation ecology of Central Europe. Cambridge: Cambridge University Press; 1988.

[40] Achermann G. The influence of red deer (Cervus elaphus L.) upon a subalpine grassland ecosystem in the Swiss National Park. Ph. D thesis, ETH Zürich; 2000.

[41] Schütz M, Wildi O, Achermann G, Krüsi B, Nievergelt B. Predicting the development of subalpine grassland in the Swiss National Park: how to build a succession model based on data from longterm permanent plots. In: Schütz M, Krüsi B, Edwards PJ, Eds. Succession research in the Swiss National Park. Zernez, Nat Park Forsch Schweiz 2000; 89: 207-235.

[42] Leuzinger E. Das zeitlich-räumliche Nutzungsmuster der Rothirsche (Cervus elaphus L.) auf der subalpinen Weide Stabelchod im Schweizerischen Nationalpark. Diploma thesis, University of Zürich; 1999.

[43] Wildi O, Schütz M. Reconstruction of a long-term recovery process from pasture to forest. Community Ecol 2000; 1:25-32.

[44] Greig-Smith P. Quantitative plant ecology. Oxford: Blackwell; 1983.

[45] SAS Institute Inc. SAS/STAT user's guide, Version 8. Cary, NC, USA; 1999.
[46] Sokal RR, Rohlf WJ. Biometry. San Francisco: Freeman; 1981.

[47] van der Maarel E. Multivariate methods in phytosociology, with reference to the Netherlands. In: Werger MJA, Eds. The study of vegetation. The Hague, Dr. W Junk Publishers, 1979; 163-225.

[48] Roberts DW. Ordination on the basis of fuzzy set theory. Vegetatio 1986; 66: 123-131.

[49] Wildi O, Orlòci L. Numerical exploration of community patterns. A guide to the use of MULVA-5. The Hague: SPB Academic Publishing; 1996.

[50] Zhukova LA, Ermakova IM. Structure and dynamics of coenopopulations of some temperate grasses. In: White J, Ed. The population structure of vegetation. Dortrecht, Dr W. Junk Publishers, $1985 ; 179-205$.

[51] Prentice I, van Tongeren O, de Smidt JT. Simulation of heathland vegetation dynamics. J Ecol 1987; 75: 203-219.

[52] Koppitz H, Kühl H. To the importance of genetic diversity of Phragmites australis in the development of reed stands. Wetlands Ecol Manage 2000; 8: 403-414.

[53] Koppitz H, Kühl H, Hesse K, Kohl JG. Some aspects of the importance of genetic diversity in Phragmites australis (Cav.) Trin. ex Steudel for the development of reed stands. Botanica Acta 1997; 110: 217-223.

[54] Bärlocher A, Schütz M, Krüsi B, Grämiger H, Schneller J. Development of species richness in mono-dominant colonies of tor grass (Brachypodium pinnatum) - an indicator of the impact of grazing upon subalpine grassland. In: Schütz M, Krüsi B, Edwards PJ, Eds. Succession research in the Swiss National Park. Zernez, Nat Park Forsch Schweiz 2000; 89: 89-105.

(C) Yu et al.; Licensee Bentham Open.

This is an open access article distributed under the terms of the Creative Commons Attribution License (http://creativecommons.org/licenses/by/2.5/), which permits unrestrictive use, distribution, and reproduction in any medium, provided the original work is properly cited. 